\title{
Evaluation of the efficacy of erector spinae plane block and intercostal nerve block in the postherpetic neuralgia
}

\author{
Postherpetik nevraljide erektör spina plan blok ve interkostal sinir bloğu etkinliğinin \\ değerlendirilmesi
}

\author{
Gülçin HACIBEYOĞLU,' Şule ARICAN,' Sinan Oğuzhan ULUKAYA, ${ }^{-}$Resul YILMAZ,' Ruhiye REisLí, \\ Sema TUNCER UZUN ${ }^{2}$
}

\begin{abstract}
Summary
Objectives: The aim of this study was to compare the efficacy of an intercostal nerve block, which has been used for many years in the treatment of postherpetic neuralgia, and the more recent alternative of an erector spinae plane (ESP) block.

Methods: The records of 39 patients who were treated in the algology department for postherpetic neuralgia between May 1, 2015 and May 1, 2018 were evaluated retrospectively. Patients who received an intercostal nerve block constituted Group 1 and those who received an ESP block were categorized as Group 2. The change in numeric rating scale (NRS) and Leeds Assessment of Neuropathic Symptoms and Signs (LANSS) scores in the short term and in the long term were the primary results of the study.

Results: The NRS, LANSS, and sleep interference scale (SIS) scores of the patients in Group 1 and Group 2 were found to be significantly lower at the $24^{\text {th }}$ hour, week 4 , and week 12 compared with the values obtained before block application. In Group 1 , the scores recorded at week 4 and week 12 were significantly higher than the $24^{\text {th }}$ hour values, whereas no difference was observed between these results in Group 2. There was no significant difference between the groups in the week 4 and week 12 scores. Similarly, no significant difference was observed in the NRS, LANSS, or SIS scores before the block application or at the $24^{\text {th }}$ hour. However, the scores at week 4 and week 12 were significantly lower in Group 2 compared with Group 1.

Conclusion: The results indicated that an ESP block significantly decreased neuropathic pain symptoms and the need for additional treatment in postherpetic neuralgia treatment in the long term.
\end{abstract}

Keywords: Erector spinae plane block; intercostal nerve block; postherpetic neuralgia.

Özet

Amaç: Bu çalışmada postherpetik nevralji tedavisinde uzun yıllardır kullanılan interkostal sinir bloğu ile yakın zamanda tanımlanan erektör spina düzlem bloğunun etkinliğinin kıyaslanması amaçlanmıştır.

Gereç ve Yöntem: 1 Mayıs 2015-1 Mayıs 2018 tarihleri arasında Necmettin Erbakan Üniversitesi Meram Tıp Fakültesi Algoloji Kliniği'nde postherpetik nevralji nedeniyle tedavi görmüş 39 hasta dosyası retrospektif olarak değerlendirildi. İnterkostal sinir bloğu yapılanlar Grup 1, erektör spina düzlem bloğu yapılanlar Grup 2 olarak kabul edildi. Kısa dönem ve uzun dönemde NRS ve LANSS skorlarındaki değişim çalışmanın birincil sonuçları olarak kabul edildi.

Bulgular: Grup 1 ve Grup 2'deki hastaların NRS, LANSS ve uyku interferans (SIS) skorlarının 24. saat, 4. hafta ve 12. hafta değerleri blok öncesine göre anlamlı derecede düşüktü. Grup 1'deki hastaların 4. hafta ve 12. hafta değerleri 24. saat değerlerine göre anlamlı derecede yüksekken Grup 2'deki hastalarda bu değerler arasında fark yoktu. 4. ve 12. hafta değerleri arasında da her iki grupta anlamlı fark yoktu. Benzer şekilde, gruplar arasında NRS, LANSS ve SIS skorları açısından blok uygulamasından önce ve 24 saat sonra anlamlı bir fark gözlenmedi. Ancak 4. ve 12. haftalardaki puanlar Grup 2'de Grup 1'e göre anlamlı olarak düşüktü. Sonuç: Bu çalışma postherpetik nevralji tedavisinde erektör spina düzlem bloğunun özellikle uzun dönemde nöropatik ağrı semptomları ile ek tedavi ihtiyacını belirgin azalttığını göstermiştir.

Anahtar sözcükler: Erektör spina düzlem bloğu; interkostal sinir bloğu; postherpetik nevralji.

\footnotetext{
'Department of Anesthesiology and Reanimation, Necmettin Erbakan University, Meram Faculty of Medicine, Konya, Turkey 2Department of Algology, Necmettin Erbakan University, Meram Faculty of Medicine, Konya, Turkey

Submitted (Başvuru tarihi) 30.10.2019 Accepted after revision (Düzeltme sonrası kabul tarihi) 08.02.2020 Available online date (Online yayımlanma tarihi) 09.07.2020

Correspondence: Dr. Gülçin Hacıbeyoğlu. Necmettin Erbakan Üniversitesi Meram Tıp Fakültesi Anesteziyoloji ve Reanimasyon Anabilim Dalı, 42800 Konya, Turkey.

Phone: +90 - 332 - 2236603 e-mail: drgulcin81@gmail.com

(c) 2020 Turkish Society of Algology
} 


\section{Introduction}

Shingles, which can be seen at any age but more common in individuals over 50 years of age, is a skin disorder involving dorsal root ganglia. It is characterized by a painful rash and is caused by the herpes zoster virus. ${ }^{[1]}$ Postherpetic neuralgia (PHN) is seen in $10-75 \%$ of patients with a herpes zoster infection history and is one of the most common causative factors of neuropathic pain. ${ }^{[2]}$ It is a neuropathic pain that significantly reduces the quality of life of patients and can lead to anxiety, depression and severe sleep disorders. ${ }^{[3]}$ Treatment of PHN is often suboptimal and effective results are achieved in less than half of the patients. Furthermore, appropriate treatment modalities for PHN are currently being investigated since the cost of drugs used in the treatment of neuropathic pain is high, the pain has a significant impact on the quality of life and there are uncertainties in the optimal treatment. ${ }^{[4]}$

The intercostal nerve block is a common analgesic method preferred to be used after rib fracture, breast surgery, PHN and thoracic surgery. Showing its activity within a short time is an advantage, however, high risk of nerve damage and pneumothorax and the requirement of multiple injections in multiple dermatome involvement are its disadvantages..$^{[5]}$ Erector spinae plane (ESP) block, which was first described by Forero in 2016 for the treatment of neuropathic pain in the thoracic region, is a new technique that provides effective analgesia. Blockage can be provided at levels 7 and 8 with a local anesthetic injected in one shot to the plane between the erector spinae muscle and vertebral transverse process. ${ }^{[6]}$

To the best of our knowledge, there are many case reports in the literature reporting the efficacy of ESP block in acute herpes zoster and PHN but there are no studies comparing intercostal nerve block and ESP block in PHN. The aim of this study was to compare the primary and secondary efficacy of intercostal nerve block, which has been used for many years in the treatment of PHN, and the efficacy of ESP block that has been defined as a new method of regional analgesia.

\section{Material and Methods}

Local Ethics Committee approval was obtained for this study (Decision no.: 2018/1381). The medical re- cords of patients who were treated for PHN between 1 May 2015 and 1 May 2018 at Necmettin Erbakan University, Meram School of Medicine, Department of Algology were evaluated retrospectively. Patients were divided into two groups: those undergoing intercostal nerve block (Group 1) and those undergoing ESP block (Group 2). Regardless of whether the patient received medical treatment for $\mathrm{PHN}$, patients who were at 18-90 years of age, had a Leeds assessment of neuropathic symptoms and signs (LANSS) score of $>12$, neuropathic pain lasting 12 weeks or more and did not undergo any interventional procedures in the past were included in the study. Exclusion criteria were the presence of any interventional procedure history in the past, neuropathic pain lasting 12 weeks or less, presence of severe systemic disease, being under 18 and over 90 years of age, not having a socio-cultural level to answer the questions, and a LANSS score of below 12. All patient files were examined for age, gender, body mass index (BMI), duration of neuropathic symptoms, presence of medication at the time of admission, and local anesthetics and adjuvants used for the block. All patients' numerical rating scale (NRS), LANSS and sleep interference scale (SIS) scores measured before the block application were examined. Scores measured at postoperative $24^{\text {th }}$ hour, week 4 and week 12 were also investigated. The severity of pain was evaluated based on the NRS score. In this scoring system, ' 0 ' means no pain and ' 10 ' means the worst possible pain. Neuropathic symptoms were evaluated by using the LANSS score. This scoring system consists of five questions about pain and a two-stage sensory examination and comprises a total of 24 points. Patients are asked to answer the questions with 'yes' or 'no'. Sensory examination is performed by the physician. The presence of allodynia and altered pinprick sensation is investigated. The effect of the pain on sleep was measured by using SIS scoring in which ' 0 ' means no interference and ' 10 ' means unable to sleep due to pain. Short-term primary efficacy of treatment was evaluated by considering the change between NRS and LANSS scores obtained before and 24 hours after the block application whereas the long-term primary efficacy was evaluated based on the change between NRS and LANSS scores obtained before and 12 weeks after the block application. Secondary efficacy of treatment was evaluated based on the change in the SIS score before and 12 weeks after block application, pain response, global 
assessment, dose change (increase or decrease) in other analgesics used at week 12, and the need for repeat interventional treatment at the end of week 12. The pain response considered as a reduction of more than $50 \%$ in the NRS score from baseline (week 0 ) to the end of week 12. The global assessment is a five-point scale used by patients at the end of week 12 for the benefit of treatment. In this scale, ' 1 ' means poor (no change in neuropathy symptoms), ' 2 ' means satisfactory (disappearance/reduction of all symptoms by $25-50 \%$ ), ' 3 ' means good (disappearance/reduction of all symptoms by $50-70 \%)$, ' 4 ' means very good (disappearance/reduction of all symptoms by $71-90 \%$ ), and ' 5 ' means excellent (disappearance/reduction of all symptoms by more than 90\%). Safety assessment of the treatment was performed based on any adverse events reported by the patients. The pharmacological treatment program routinely applied by the clinic for patients, who were not on medication at the time of admission, was planned according to the patient's tolerance and clinical needs. Pregabalin was started at a dose of $150 \mathrm{mg} /$ day and increased by titrating, during follow-up, when necessary. An opioid with a weak activity was added to the treatment and dose was adjusted according to the patient's needs. The treatment of the patients who were on medication at the time of admission was continued as the same. However, dose was adjusted according to the procedure for patients with a NRS score of $>4$ following the intervention. Moreover, intervention was recommended to be repeated in patients with a NRS score of $>4$ during follow-up, and the intervention was repeated for those who provided consent. Prior to block procedures, all patients were given oxygen through a nasal cannula and electrocardiogram, noninvasive blood pressure, and oxygen saturation via pulse oximeter were applied and monitored.

\section{Intercostal block application}

The involved dermatome regions and related intercostal space are determined and aseptic conditions are provided. While the patient is in the sitting position, a 22-gauge $50-\mathrm{mm}$ long needle is placed through the upper line of the lower rib. The needle is advanced until it contacts the lower line of the upper rib at a depth of $1 \mathrm{~cm}$ with a 20-degree angle cephalad. The needle is then advanced $3 \mathrm{~mm}$ into the area of the neurovascular bundle which is between the internal and innermost intercostal muscles. Follow-

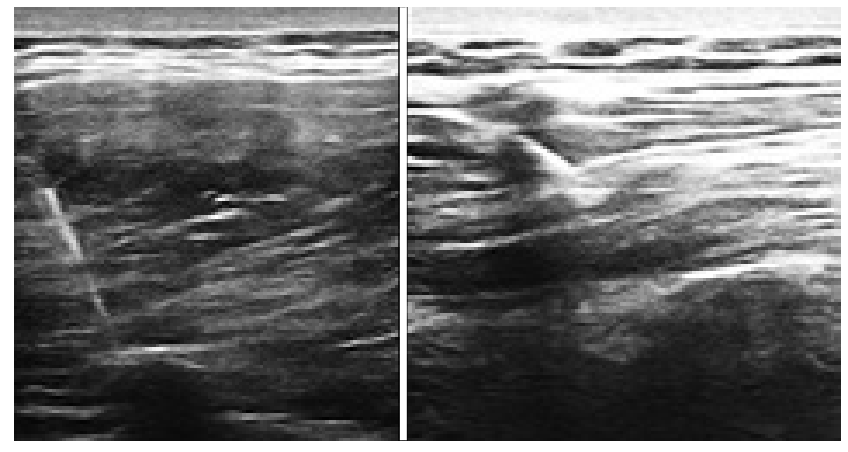

Figure 1. Sonographic image of ESP block.

ing negative aspiration for blood or air, $2 \mathrm{~mL}$ from a mixture of $20 \mathrm{~mL}$ bupivacaine $\mathrm{HCl} 0.25 \%+8 \mathrm{mg}$ dexamethasone is injected for each level.

\section{ESP block application}

Patients are placed in the prone position to determine the vertebrae in the middle of the involved area. Following the provision of aseptic conditions, the spinous process of the vertebral midline is visualized using a high-frequency $(8 \mathrm{MHz})$ linear ultrasound (USG) probe. The transverse process is, then, visualized approximately at the $3 \mathrm{~cm}$ lateral from the midline and the erector spinae muscle is visualized on it. The 22-gauge $50 \mathrm{~mm}$ block needle is advanced towards the in-plane section craniocaudally and the transverse process is touched. Then the needle is then withdrawn minimally to confirm that it is between the erector spinae muscle and the transverse process through hydrodissection. Following that, 20 $\mathrm{mL}$ from $0.25 \%$ bupivacaine $\mathrm{HCl}+8 \mathrm{mg}$ dexamethasone is administered and local anesthetic spread is confirmed by USG (Fig. 1).

\section{Statistical method}

Statistical analysis was carried out using the SPSS version 23.0 software. Frequencies of general demographic characteristics and descriptive statistical values of time-dependent measurements were determined. Shapiro-Wilk test was used to determine whether the scores were normally distributed if the sample size was below 30 whereas the KolmogorovSmirnov test was used for the sample sizes above 30. A $p$ value of $<0.05$ indicated a non-normally distribution between the groups whereas a $p$ value of $>0.05$ indicated a normal distribution. Following the normality test, Mann-Whitney $U$ test was used to examine the differences between the groups. Chi-square test was used to investigate intergroup dependency in the categorical data. In the analysis of intergroup 
Table 1. Demographic characteristics of groups

\begin{tabular}{lccc}
\hline & $\begin{array}{c}\text { Group 1 } \\
(\mathbf{n = 1 8 )}\end{array}$ & $\begin{array}{c}\text { Group 2 } \\
(\mathbf{n = 2 1 )}\end{array}$ & $\mathbf{p}$ \\
\hline Gender (M/F) & $6 / 12$ & $7 / 14$ & 1.000 \\
Age (year) & $52.0 \pm 17.6$ & $57.3 \pm 12.9$ & 0.225 \\
BMl (kg/m ${ }^{2}$ ) & $26.16 \pm 3.64$ & $27.81 \pm 3.87$ & 0.124 \\
$\begin{array}{l}\text { Duration of symptom } \\
\text { (weeks) }\end{array}$ & $18 \pm 6.7$ & $21 \pm 2.2$ & 0.428 \\
\hline
\end{tabular}

M: Male; F: Female; BMI: Body mass index.

differences and dependence, 0.05 was used as the level of significance; $p<0.05$ indicated a significant difference between the groups whereas $p>0.05$ indicated no significant difference between the groups. Wilcoxon signed-rank test was used for intragroup comparisons; $p<0.05$ indicated that the measured values varied with time whereas $p>0.05$ indicated that the measured values did not varied with time.

\section{Results}

The files of 39 patients who met the study criteria and had sufficient medical records were reviewed retrospectively. Eighteen patients undergoing intercostal block were identified as Group 1 and 21 patients undergoing ESP block were identified as Group 2. Of the 39 patients, 26 (66.7\%) were female and 13 (33.3\%) were male. The mean age of the patients was $54.9 \pm 15.3$ years and mean BMI was $27.0 \pm 3.8$. There was no statistically significant difference between the groups in terms of demographic characteristics (Table 1). Of the patients in Group 1, $77.8 \%$ had a history of pharmacological treatment at the time of admission whereas this rate was $85.7 \%$ in Group 2.

In Group 1, NRS scores at $24^{\text {th }}$ hour, week 4 and week 12 were found to be significantly lower compared to the baseline (week 0 ) scores whereas the NRS scores at week 4 and week 12 were significantly higher than 24-hour NRS scores. No statistically significant difference was observed between NRS scores at week 4 and week 12. In Group 2, NRS scores at $24^{\text {th }}$ hour, week 4 and week 12 was significantly lower compared to the baseline (week 0 ) and no significant difference was observed between NRS scores at week 4 and week 12 and 24-hour NRS scores. There was no statistically significant difference between NRS scores at week 4 and week 12 (Table 2).

In Group 1, LANSS scores at $24^{\text {th }}$ hour, week 4 and week 12 were found to be significantly lower compared to the baseline (week 0 ) scores whereas the LANSS scores at week 4 and week 12 were significantly higher than 24-hour LANSS scores. There was no statistically significant difference between LANSS scores at week 4 and week 12. In Group 2, LANSS scores at 24 ${ }^{\text {th }}$ hour, week 4 and week 12 was significantly lower compared to the baseline (week 0). Although there was no significant difference between LANSS scores at week 4 and week

Table 2. Changes in the NRS scores in Group 1 and Group 2

\begin{tabular}{|c|c|c|c|c|c|c|c|c|}
\hline & \multicolumn{2}{|c|}{ Group 1} & \multicolumn{2}{|c|}{$\begin{array}{l}\text { Wilcoxon } \\
\text { signed-rank test }\end{array}$} & \multicolumn{2}{|c|}{ Group 2} & \multicolumn{2}{|c|}{$\begin{array}{c}\text { Wilcoxon } \\
\text { signed-rank test }\end{array}$} \\
\hline & $\mathbf{n}$ & Mean \pm SD & $\mathbf{z}$ & $\mathbf{p}$ & $\mathbf{n}$ & Mean \pm SD & $\mathbf{z}$ & $\mathbf{p}$ \\
\hline Baseline NRS & 18 & $7.3 \pm 1.1$ & \multirow{2}{*}{-3.778} & \multirow{2}{*}{0.000} & 21 & $7.4 \pm 1.2$ & \multirow{2}{*}{-4.026} & \multirow{2}{*}{0.000} \\
\hline 24-hour NRS & 18 & $1.1 \pm 1.5$ & & & 21 & $1.1 \pm 1.8$ & & \\
\hline Baseline NRS & 18 & $7.3 \pm 1.1$ & \multirow{2}{*}{-2.966} & \multirow{2}{*}{0.003} & 21 & $7.4 \pm 1.2$ & \multirow{2}{*}{-4.029} & \multirow{2}{*}{0.000} \\
\hline NRS at week 4 & 18 & $5.6 \pm 2.5$ & & & 21 & $1.3 \pm 1.6$ & & \\
\hline Baseline NRS & 18 & $7.3 \pm 1.1$ & \multirow{2}{*}{-3.086} & \multirow{2}{*}{0.002} & 21 & $7.4 \pm 1.2$ & \multirow{2}{*}{-4.033} & \multirow{2}{*}{0.000} \\
\hline NRS at week 12 & 18 & $5.4 \pm 2.4$ & & & 21 & $1.4 \pm 1.8$ & & \\
\hline 24-hour NRS & 18 & $1.1 \pm 1.5$ & \multirow{2}{*}{-3.531} & \multirow{2}{*}{0.000} & 21 & $1.1 \pm 1.8$ & \multirow{2}{*}{-0.466} & \multirow{2}{*}{0.641} \\
\hline NRS at week 4 & 18 & $5.6 \pm 2.5$ & & & 21 & $1.3 \pm 1.6$ & & \\
\hline 24-hour NRS & 18 & $1.1 \pm 1.5$ & \multirow{2}{*}{-3.427} & \multirow{2}{*}{0.001} & 21 & $1.1 \pm 1.8$ & \multirow{2}{*}{-0.567} & \multirow{2}{*}{0.571} \\
\hline NRS at week 12 & 18 & $5.4 \pm 2.4$ & & & 21 & $1.4 \pm 1.8$ & & \\
\hline NRS at week 4 & 18 & $5.6 \pm 2.5$ & \multirow{2}{*}{-0.520} & \multirow{2}{*}{0.603} & 21 & $1.3 \pm 1.6$ & \multirow{2}{*}{-0.743} & \multirow{2}{*}{0.458} \\
\hline NRS at week 12 & 18 & $5.4 \pm 2.4$ & & & 21 & $1.4 \pm 1.8$ & & \\
\hline
\end{tabular}

NRS: Numerical rating scale; SD: Standard deviation. 
Table 3. Changes in the LANSS scores in Group 1 and Group 2

\begin{tabular}{|c|c|c|c|c|c|c|c|c|}
\hline & \multicolumn{2}{|c|}{ Group 1} & \multicolumn{2}{|c|}{$\begin{array}{l}\text { Wilcoxon } \\
\text { signed-rank test }\end{array}$} & \multicolumn{2}{|c|}{ Group 2} & \multicolumn{2}{|c|}{$\begin{array}{c}\text { Wilcoxon } \\
\text { signed-rank test }\end{array}$} \\
\hline & $\mathbf{n}$ & Mean \pm SD & $\mathbf{z}$ & $\mathbf{p}$ & $\mathbf{n}$ & Mean \pm SD & $\mathbf{z}$ & $\mathbf{p}$ \\
\hline Baseline LANSS & 18 & $16.4 \pm 1.6$ & \multirow{2}{*}{-3.764} & \multirow{2}{*}{0.000} & 21 & $16.4 \pm 2.1$ & \multirow{2}{*}{-4.044} & \multirow{2}{*}{0.000} \\
\hline 24-hour LANSS & 18 & $2.6 \pm 3.8$ & & & 21 & $2.1 \pm 2.8$ & & \\
\hline Baseline LANSS & 18 & $16.4 \pm 1.6$ & \multirow{2}{*}{-3.359} & \multirow{2}{*}{0.001} & 21 & $16.4 \pm 2.1$ & \multirow{2}{*}{-4.030} & \multirow{2}{*}{0.000} \\
\hline LANSS at week 4 & 18 & $12.9 \pm 3.0$ & & & 21 & $2.7 \pm 3.3$ & & \\
\hline Baseline LANSS & 18 & $16.4 \pm 1.6$ & \multirow{2}{*}{-3.321} & \multirow{2}{*}{0.001} & 21 & $16.4 \pm 2.1$ & \multirow{2}{*}{-4.028} & \multirow{2}{*}{0.000} \\
\hline LANSS at week 12 & 18 & $12.4 \pm 2.7$ & & & 21 & $3.2 \pm 4.0$ & & \\
\hline 24-hour LANSS & 18 & $2.6 \pm 3.8$ & \multirow{2}{*}{-3.753} & \multirow{2}{*}{0.000} & 21 & $2.1 \pm 2.8$ & \multirow{2}{*}{-0.639} & \multirow{2}{*}{0.523} \\
\hline LANSS at week 4 & 18 & $12.9 \pm 3.0$ & & & 21 & $2.7 \pm 3.3$ & & \\
\hline 24-hour LANSS & 18 & $2.6 \pm 3.8$ & \multirow{2}{*}{-3.541} & \multirow{2}{*}{0.000} & 21 & $2.1 \pm 2.8$ & \multirow{2}{*}{-1.035} & \multirow{2}{*}{0.301} \\
\hline LANSS at week 12 & 18 & $12.4 \pm 2.7$ & & & 21 & $3.2 \pm 4.0$ & & \\
\hline LANSS at week 4 & 18 & $12.9 \pm 3.0$ & \multirow{2}{*}{-0.957} & \multirow{2}{*}{0.339} & 21 & $2.7 \pm 3.3$ & \multirow{2}{*}{-1.512} & \multirow{2}{*}{0.131} \\
\hline LANSS at week 12 & 18 & $12.4 \pm 2.7$ & & & 21 & $3.2 \pm 4.0$ & & \\
\hline
\end{tabular}

LANSS: Leeds assessment of neuropathic symptoms and signs; SD: Standard deviation.

Table 4. Changes in the SIS scores in Group 1 and Group 2

\begin{tabular}{|c|c|c|c|c|c|c|c|c|}
\hline & \multicolumn{2}{|c|}{ Group 1} & \multicolumn{2}{|c|}{$\begin{array}{l}\text { Wilcoxon } \\
\text { signed-rank test }\end{array}$} & \multicolumn{2}{|c|}{ Group 2} & \multicolumn{2}{|c|}{$\begin{array}{c}\text { Wilcoxon } \\
\text { signed-rank test }\end{array}$} \\
\hline & $\mathbf{n}$ & Mean \pm SD & $\mathbf{z}$ & $\mathbf{p}$ & $\mathbf{n}$ & Mean \pm SD & $\mathbf{z}$ & $\mathbf{p}$ \\
\hline Baseline SIS & 18 & $5.4 \pm 1.3$ & -3.826 & 0.000 & 21 & $4.6 \pm 1.9$ & -4.042 & 0.000 \\
\hline 24-hour SIS & 18 & $0.3 \pm 0.8$ & & & 21 & $0.5 \pm 0.8$ & & \\
\hline Baseline SIS & 18 & $5.4 \pm 1.3$ & -3.555 & 0.000 & 21 & $4.6 \pm 1.9$ & -3.946 & 0.000 \\
\hline SIS at week 4 & 18 & $3.2 \pm 1.8$ & & & 21 & $0.6 \pm 1.0$ & & \\
\hline Baseline SIS & 18 & $5.4 \pm 1.3$ & -2.963 & 0.003 & 21 & $4.6 \pm 1.9$ & -3.842 & 0.000 \\
\hline SIS at week 12 & 18 & $3.7 \pm 2.2$ & & & 21 & $0.7 \pm 1.2$ & & \\
\hline 24-hour SIS & 18 & $0.3 \pm 0.8$ & -3.541 & 0.000 & 21 & $0.5 \pm 0.8$ & -0.866 & 0.386 \\
\hline SIS at week 4 & 18 & $3.2 \pm 1.8$ & & & 21 & $0.6 \pm 1.0$ & & \\
\hline 24-hour SIS & 18 & $0.3 \pm 0.8$ & -3.55 & 0.000 & 21 & $0.5 \pm 0.8$ & -0.690 & 0.490 \\
\hline SIS at week 12 & 18 & $3.7 \pm 2.2$ & & & 21 & $0.7 \pm 1.2$ & & \\
\hline SIS at week 4 & 18 & $3.2 \pm 1.8$ & -2.081 & 0.037 & 21 & $0.6 \pm 1.0$ & -0.447 & 0.655 \\
\hline SIS at week 12 & 18 & $3.7 \pm 2.2$ & & & 21 & $0.7 \pm 1.2$ & & \\
\hline
\end{tabular}

SIS: Sleep interference scale; SD: Standard deviation.

12 and 24-hour LANSS scores, scores at week 12 were found to be higher than the 24-hour scores. There was no statistically significant difference between LANSS scores at week 4 and week 12 , but scores at week 12 were found to be higher (Table 3 ).

In Group 1, SIS scores at $24^{\text {th }}$ hour, week 4 and week 12 were found to be significantly lower compared to the baseline (week 0) scores whereas the SIS scores at week 4 and week 12 were significantly higher than 24-hour SIS scores. The SIS scores at week 12 were significantly higher than the SIS scores at week 4 . In Group 2, SIS scores at $24^{\text {th }}$ hour, week 4 and week 12 were significantly lower compared to the baseline (week 0). There was no significant difference between the SIS scores at week 4 and week 12 and 24hour SIS scores and between the SIS scores at week 4 and week 12 (Table 4). 


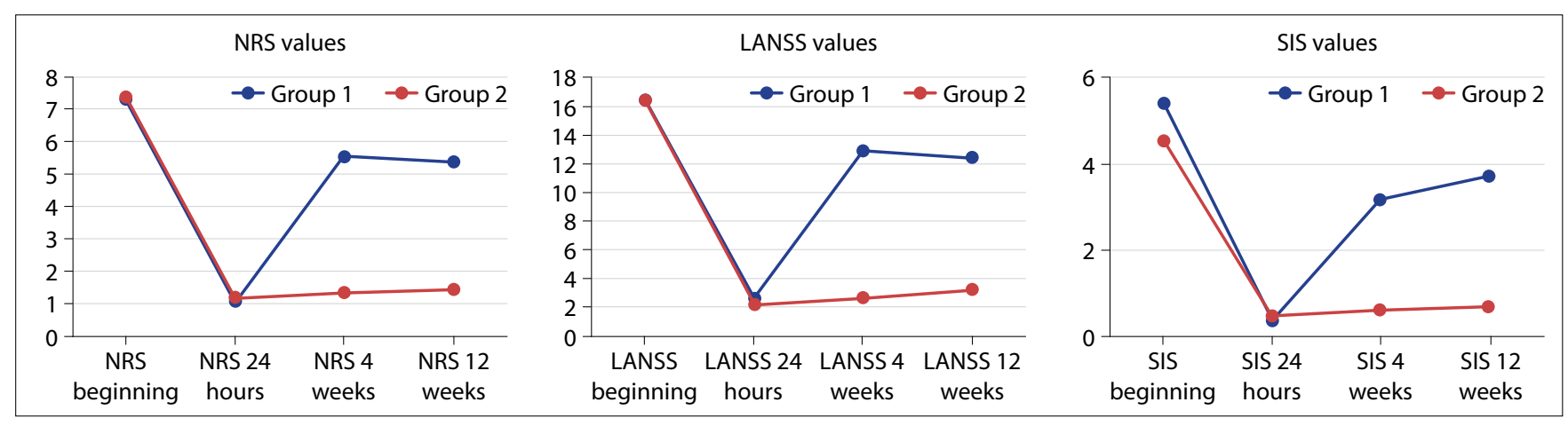

Figure 2. Changes in the NRS, LANSS, and SIS scores of groups by time.

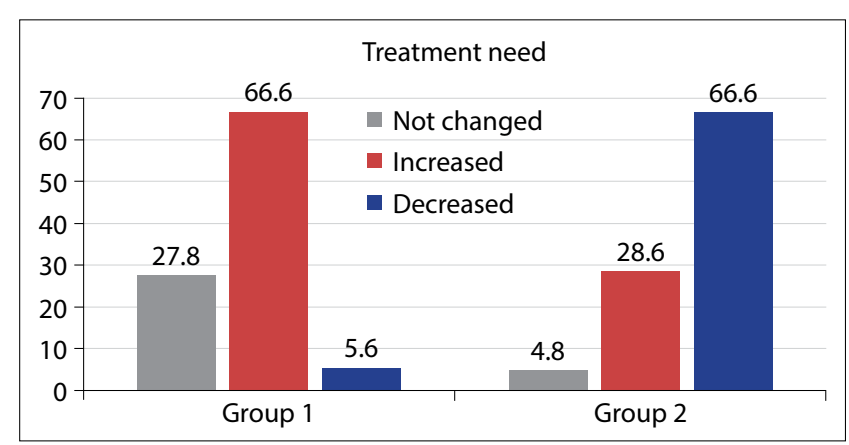

Figure 3. Change in drug doses at the end of week 12.

There was no statistically significant difference between the groups in terms of baseline and 24-hour NRS scores ( $p>0.05$ ). In Group 2, NRS scores at week 4 were found to be significantly lower than in Group 1. Similarly, NRS scores at week 12 were significantly lower in Group 2. There was no significant difference between the groups in terms of baseline and 24hour LANSS scores, but there was a statistically significant difference in terms of LANSS scores at week 4 and week $12(p<0.05)$. Group 2 had significantly lower LANSS scores at week 4 and week 12 compared to Group 1 (Fig. 2). Although there was no statistically significant difference between the groups in terms of baseline and 24-hour SIS scores, baseline SIS scores of Group 1 were found to be higher than Group 2. Group 2 had significantly lower SIS scores at week 4 and week 12 compared to Group 1 (Fig. 2).

At the end of week 12, the need for treatment of $66.6 \%$ of the patients in Group 1 increased whereas the need for treatment decreased by the same rate in Group 2. Figure 3 shows the change from the baseline to week 12 in the drug doses used by the patients.

A statistically significant difference was observed in pain response between groups in terms of baseline and 12-week scores ( $p<0.05)$ (Fig. 4).

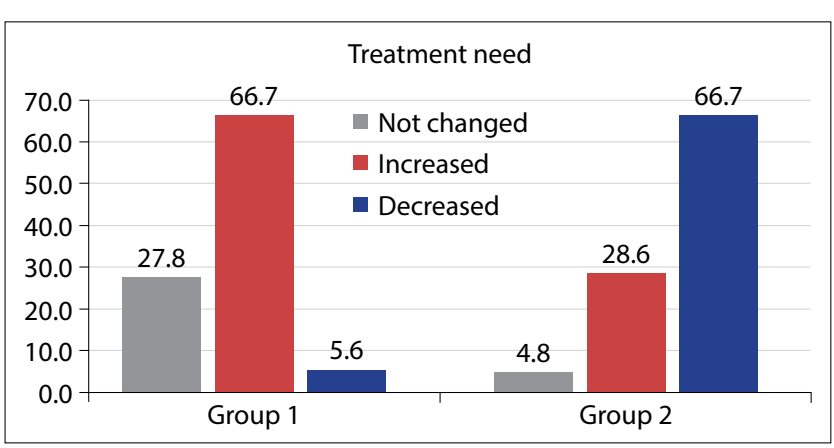

Figure 4. Pain response of patients (\%).

The procedure had to be repeated in $14.3 \%$ of the patients in Group 2 whereas this rate was $61.1 \%$ in Group 1 . This difference was statistically significant $(p<0.05)$. There was a statistically significant difference between the groups in terms of global assessment $(p<0.05)$. The mean global assessment scores were $1.3 \pm 0.8$ and $4.0 \pm 1.2$ in Group 1 and Group 2, respectively. No complication was observed in any of the patients. The mean dermatomes blocked via ESP were found to be $7.4 \pm 0.9$.

\section{Discussion}

In this study, the primary and secondary efficacy of intercostal nerve block and ESP block in the treatment of PHN pain has been evaluated. Although the two methods have been found to be not superior to each other in terms of short-term primary efficacy, ESP block has been observed to be superior to the other method in terms of long-term primary and secondary efficacy.

The virus remains dormant within the dorsal root and cranial nerve ganglia following the primary infection caused by the varicella-zoster virus. Herpes zoster infection occurs due to the reactivation of the primary infection, resulting in typical dermatomal pain and vesicular rash. Postherpetic neuralgia is defined as pain resuming for 12 weeks following the re- 
activation of the virus. ${ }^{[7]}$ The pain can be intermittent or constant and is typically described as burning, stabbing, or shooting, which may have a severe impact on the quality of sleep and life. Being over the age of 60 and female sex are risk factors for PHN. ${ }^{[8]}$ Compatible with the literature, $66.7 \%$ of the patients included in our study were females.

Various interventional procedures, including intercostal nerve blocks, epidural block, paravertebral block, and spinal cord stimulation, have been described in the treatment of thoracic neuropathic pain. However, these procedures are technically difficult to perform, invasive, and may be associated with significant failure rates. ${ }^{[9]}$ Erector spinae plane block, which was first described by Forero for the treatment of thoracic neuropathic pain, is a new plane block that has proven efficacy for different indications in different areas of the body and has become popular in the recent years. ${ }^{[6]} \mathrm{Ca}-$ daver studies have shown that the local anesthetic injected during the block application targets ventral rami, dorsal rami and rami communicantes and spreads towards epidural, neural foraminal and intercostal regions. ${ }^{[10,11]}$ Thus, the block shows its efficacy on both the posterior and anterolateral walls of the thorax. Therefore, ESP block can be used in the treatment of PHN. It can be an alternative method for the management of thoracic neuropathic pain since it is easier to apply and theoretically safer than other techniques when applied under USG guidance and its efficiency has been proven in many case reports. ${ }^{[6,12,13]}$ Although the risk of complications seems to be lower in ESP block compared to other blocks used in the treatment of PHN such as intercostal block and paravertebral block, there is no randomized controlled trial in the literature that proves its efficacy and safety in this indication. Therefore, potential risks such as pneumothorax, hematoma, and local anesthetic toxicity should not be ignored. In the present study, no complication was reported in any of the patients undergoing ESP block. Furthermore, long-term primary efficacy parameters and secondary efficacy parameters including sleep patterns, pain response, and global activity have been found to be superior in patients undergoing ESP block compared to patients undergoing intercostal block. Therefore, we believe that the ESP block can be used safely and effectively in the treatment of PHN when performed under USG guidance.

Reports on the efficacy of ESP block in acute herpes zoster or PHN are limited to case reports, most of which are related to the management of acute herpes pain. Furthermore, there are differences between these case reports in terms of the local anesthetic agent used, adjuvant use, dose, and volume. In one of the case reports, the ESP block was performed without making any alterations in the previous medication the NRS score of the patient, which was 10 before the application, was found to decrease to 3 after block application. One-month cure was achieved in the patient who was given the combination of methylprednisolone and local anesthetic during the block. Antiviral, gabapentinoids, and analgesics were reported to be continued after the block procedure. ${ }^{[14]}$ In a study by Alici et al., ${ }^{[12]}$ ESP block was performed with a mixture of $40 \mathrm{~mL}$ of bupivacaine, methylprednisolone, and lidocaine in a patient with an NRS score of 10, who was diagnosed with herpes zoster two weeks ago and had T10-S2 dermatomes involvement, and authors reported that cure was achieved without the need for additional analgesics for two months. Tekin et al. ${ }^{[15]}$ performed a high thoracic ESP block for acute herpes zoster pain involving the cervicothoracic and shoulder region by using the mixture of $10 \mathrm{~mL} 2 \%$ lidocaine, $10 \mathrm{~mL}$ $0.25 \%$ bupivacaine and $40 \mathrm{mg}$ methylprednisolone acetate to block the C3-T6 dermatomes. They reported that the NRS score of the patient, which was 10 at the beginning of treatment, did not exceed 3 in the first-month follow-up. In a study by Ahiskalığlu et

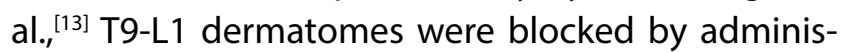
tering of $20 \mathrm{~mL}$ of $0.25 \%$ bupivacaine from T10 for acute herpes zoster pain. The authors reported that the pain was significantly alleviated and no analgesic agent was required for the first six hours, but a catheter placement was required after 24 hours. We attribute the short duration of analgesia in this case to the absence of adjuvant use, unlike the other cases. In our clinic, adjuvants are certainly used together with local anesthetics for patients who received interventional treatment due to neuropathic pain. We believe that the use of adjuvants prolongs the duration of analgesia. The ongoing improvement in the NRS and LANSS scores from the baseline to week 4 and week 12 in both groups also supports this. 
Nerve blocks combining local anesthetic and corticosteroids are widely used in the treatment of herpes zoster and $\mathrm{PHN}$ pain. ${ }^{[16]}$ Steroid injections may potentially contribute to analgesia by suppressing abnormal pain transmissions in damaged nerves, providing the modulation of transmission in normal nerves, and showing an anti-inflammatory effect. ${ }^{[17]}$ Herpes zoster is associated with inflammation of the dorsal root ganglion and peripheral nerves, which is an important factor for the development of PHN. Therefore, the treatment of PHN should be aimed at reducing inflammation. ${ }^{[18]}$ The literature review has shown that there is no study investigating the clinical effects of adjuvant use on ESP block applications in PHN cases. However, there are case reports showing that analgesic requirement decreases and analgesia duration increases when steroids are used as adjuvants in ESP block which is applied in many different indications such as chronic neuropathic pain and postoperative analgesia. ${ }^{[19-22]}$ In our clinic, we often prefer dexamethasone as an adjuvant in interventional techniques used in the treatment of neuropathic pain. In the present study, $8 \mathrm{mg}$ dexamethasone was used as an adjuvant in both groups. A significant reduction was observed in the NRS and LANSS scores at week 12 in both groups compared to the baseline scores. We believe that long-term significant improvement achieved via ESP block is due to the fact that the ESP block provides simultaneous blockage in the paravertebral, prevertebral and intercostal areas, in other words, it acts similarly to the central block. Furthermore, injection of local anesthesia at multiple intercostal levels increases the metabolism rate of the drug and shortens the block duration due to increased vascularity in this region. The ESP block is an avascular plane block and we believe that this feature probably increases the efficacy of the block because it is associated with low absorption rates.

As in all plane blocks, the volume of local anesthetics influences the spread in the ESP block. In cadaver studies, in which block was performed at the T5 level using a $20 \mathrm{~mL}$ solution, the spread has been reported to be at five and three levels in the intercostal and epidural plane, respectively. ${ }^{[23]}$ Schwartzmann et al. ${ }^{[24]}$ reported that $30 \mathrm{~mL}$ of local anesthetic injected from the T10 level produced spread between the T5 and T12 levels. Ahiskalioglu et al. ${ }^{[13]}$ reported that they achieved blockage in five dermatomes with 20
$\mathrm{mL}$ local anesthetic, Alici et al. ${ }^{[12]}$ reported that they achieved blockage in 10 dermatomes with $40 \mathrm{~mL}$ local anesthetic, and Tekin et al. ${ }^{[15]}$ reported that they achieved blockage in 10 dermatomes with $20 \mathrm{~mL}$ local anesthetic in the high thoracic block. In a study by De Cassai et al., ${ }^{[25]}$ in which the local anesthetic volume required for each dermatome in the ESP block was investigated, the authors concluded that $3.4 \mathrm{~mL}(2.5-6.6 \mathrm{~mL})$ of local anesthetic was required for a single dermatome. We used $20 \mathrm{~mL}$ local anesthetic in all 20 patients undergoing ESP block and found that the mean number of dermatomes, where the blockage was achieved, was 7.4 \pm 0.9 , compatible with the study by De Cassai.

Studies on the efficacy of intercostal nerve block in postoperative analgesia particularly in patients undergoing thoracotomy and mammoplasty showed that this technique was as effective as other methods in the early period. ${ }^{[26-28]}$ Intercostal nerve block has been further reported to reduce the incidence of chronic pain after thoracotomy. ${ }^{[29]}$ Despite being a simple technique, it has not gained popularity in clinical practice particularly in patients who will undergo multiple dermatome blocks since it requires several repeated injections that increase the risk of pneumothorax and local anaesthetic toxicity. There are very few reports on the efficacy of intercostal nerve blocks in patients with herpes zoster. Doi et al. ${ }^{[30]}$ reported an effective series of intercostal nerve block with $5 \%$ tetracaine. In another study by Reiestad et al., ${ }^{\left[{ }^{13]}\right.}$ intercostal nerve block inserted into the catheter has been reported to be effective in patients with acute or subacute herpes zoster. As in other peripheral blocks, the use of steroids as adjuvants in the intercostal nerve block has been shown to prolong the block duration. Lee et al. ${ }^{[32]}$ compared the efficacy of conventional fluoroscopy-guided ESP block and USG-guided intercostal nerve block in patients with herpes zoster. Block was applied with 5 $\mathrm{mL}$ of $2.5 \mathrm{mg}$ dexamethasone and $0.5 \%$ lidocaine combination. Compared to the baseline scores, a significant pain reduction was observed in both groups at the last visit. The USG-guided intercostal nerve block, which is more accessible than a fluoroscopyguided ESP block, has been reported to be an alternative treatment method for thoracic herpes zoster pain. In the present study, the efficacy of intercostal block applied through a conventional blind proce- 
dure and USG-guided ESP block in patients with PHN was investigated. We used $2 \mathrm{~mL}$ from the mixture of $0.25 \%$ bupivacaine and $8 \mathrm{mg}$ dexamethasone for each level in the intercostal block and $20 \mathrm{~mL}$ for ESP block. Similarly, a significant pain reduction could be achieved via both methods compared to baseline. Although there was no significant difference between the two methods in terms of short-term efficacy, the ESP block was seen to be significantly superior to the intercostal block in the long term. Therefore, we believe that intercostal block should be preferred as a part of multimodal therapy in cases where shortterm relief is required such as patients with acute herpes pain or rib fracture, however, techniques with a long-term efficacy, ESP block for instance, should be preferred in chronic and treatment-resistant clinical conditions such as PHN.

Neuropathic pain is associated with sleep disorders and pain sensitivity increases due to poor sleep quality. Therefore, it is important to assess sleep, as well as neuropathic pain. Sleep disturbances decrease the quality of life and cause high health care costs and therefore, multimodal methods should be applied to improve the quality of life effectively. ${ }^{[3]}$ Pregabalin is one of the most commonly prescribed analgesics for PHN. In many clinical studies, pregabalin used for PHN has been shown to reduce pain significantly, to improve sleep more compared to placebo, to have higher global efficacy, and to provide great improvement in patients with severe sleep disorders. ${ }^{[34-37]}$ In the present study, pregabalin was seen to be the most commonly preferred drug in both groups. Fourteen patients in Group 1 and 16 patients in Group 2 were receiving pregabalin in their treatment. We believe that pregabalin has a significant effect on the improvement of SIS scores at $24^{\text {th }}$ hour, week 4 and week 12 in both groups. Furthermore, we attribute the significant improvement in the 24-hour SIS scores in both groups to the use of interventional methods. However, the improvement in SIS scores at week 4 and week 12 in the group undergoing ESP was not at the same rate in the group undergoing intercostal block. This suggests that the ESP block is more effective than the intercostal block in the long term.

Although pregabalin and gabapentin are effective agents, the drugs should be titrated to achieve the optimum dose for clinical efficacy and this may take up to 10 weeks and their side effects may also limit their use. ${ }^{[38]}$ Therefore, interventional treatment modalities and multimodal approaches are gaining importance in patients suffering from chronic neuropathic pain, such as PHN, which is difficult to treat. Interventional methods such as ESP, transforaminal epidural injection, or pulse radiofrequency applications have been shown to reduce drug efficacy and consumption in patients with herpes zoster. ${ }^{[39,40]}$ In the present study, the need for treatment was observed to decrease in $66.7 \%$ of patients in the ESP block group at the end of week 12 whereas the need for treatment was observed to increase in patients in the intercostal block group at the end of week 12 . Furthermore, the procedure had to be repeated only in $14.3 \%$ of the patients undergoing ESP whereas this rate was $61.1 \%$ in patients undergoing intercostal block. The difference between the groups was statistically significant. We believe that this is due to the decrease in the long-term efficacy of the blockage due to the absorption of the agents used in the intercostal block into the systemic circulation.

\section{Limitations}

There are some limitations of the present study. Firstly, it was designed as a retrospective study and therefore, other factors of multimodal treatment such as analgesic and anticonvulsant dose could not be fully standardized. Secondly, the intercostal block was performed with conventional blind method and the ESP block was performed under USG guidance. If both methods were performed under USG guidance, the efficacy of the methods could be evaluated more objectively. Furthermore, different volumes and different drug doses were used since one of the blocks was a peripheral nerve block and the other was a plane block. Small sample size and the shortterm follow-up of the patients were among other limitations. Nevertheless, this is the first study that compares the efficacy of ESP and intercostal nerve block in the treatment of PHN. There is a need for prospective randomized controlled trials with larger sample sizes and longer follow-up periods to provide stronger evidence.

\section{Conclusion}

In conclusion, this study has shown that ESP block significantly reduces neuropathic pain symptoms and 
the need for additional treatment in the treatment of PHN compared to the intercostal nerve block. It further has positive effects on sleep patterns. Moreover, a great number of randomized controlled trials are needed to demonstrate the superiority of ESP block over other techniques and to optimize drug doses to be applied. We believe that the long-term efficacy of ESP block is promising in the treatment of PHN and we recommend its use in routine clinical practice.

\section{Ethics Committee Approval: The Necmettin Erbakan Uni- versity, Meram Medical Faculty Medicine and Non-Medi- cal Device Research Ethics Committee granted approval for this study (date: 01.06.2018, number: 2018/1381).}

\section{Conflict-of-interest issues regarding the authorship or article: None declared.}

\section{Peer-rewiew: Externally peer-reviewed.}

\section{References}

1. Le $P$, Rothberg $M$. Herpes zoster infection. BMJ 2019;364:k5095. [CrossRef]

2. Dubinsky RM, Kabbani H, El-Chami Z, Boutwell C, Ali H; Quality Standards Subcommittee of the American Academy of Neurology. Practice parameter: treatment of postherpetic neuralgia: an evidence-based report of the Quality Standards Subcommittee of the American Academy of Neurology. Neurology 2004;63(6):959-65. [CrossRef]

3. Doth $A H$, Hansson PT, Jensen MP, Taylor RS. The burden of neuropathic pain: a systematic review and meta-analysis of health utilities. Pain 2010;149(2):338-44. [CrossRef]

4. Schutzer-Weissmann J, Farquhar-Smith P. Post-herpetic neuralgia - a review of current management and future directions. Expert Opin Pharmacother 2017;18(16):1739-50.

5. Roué $C$, Wallaert $M$, Kacha $M$, Havet E. Intercostal/paraspinal nerve block for thoracic surgery. Anaesthesia 2016;71(1):112-3. [CrossRef]

6. Forero M, Adhikary SD, Lopez H, Tsui C, Chin KJ. The Erector Spinae Plane Block: A Novel Analgesic Technique in Thoracic Neuropathic Pain. Reg Anesth Pain Med 2016;41(5):621-7.

7. Opstelten W, Zuithoff NP, van Essen GA, van Loon AM, van Wijck AJ, Kalkman CJ, et al. Predicting postherpetic neuralgia in elderly primary care patients with herpes zoster: prospective prognostic study. Pain 2007;132 Suppl 1:S52-9.

8. Drolet $M$, Brisson M, Schmader K, Levin M, Johnson R, Oxman $M$, et al. Predictors of postherpetic neuralgia among patients with herpes zoster: a prospective study. J Pain 2010;11(11):1211-21. [CrossRef]

9. Romero A, Garcia JE, Joshi GP. The state of the art in preventing postthoracotomy pain. Semin Thorac Cardiovasc Surg 2013;25(2):116-24. [CrossRef]

10. Ivanusic J, Konishi Y, Barrington MJ. A Cadaveric Study Investigating the Mechanism of Action of Erector Spinae Blockade. Reg Anesth Pain Med 2018;43(6):567-71. [CrossRef]

11. Ueshima $H$, Hiroshi O. Spread of local anesthetic solution in the erector spinae plane block. J Clin Anesth 2018;45:23.

12. Alici HA, Ahiskalioglu A, Aydin ME, Ahiskalioglu EO, Celik $M$. High volume single injection lumbar erector spinae plane block provides effective analgesia for lower extremity herpes zoster. J Clin Anesth 2019;54:136-7. [CrossRef]

13. Ahiskalioglu A, Alici HA, Ari MA. Ultrasound guided low thoracic erector spinae plane block for management of acute herpes zoster. J Clin Anesth 2018;45:60-1. [CrossRef]

14. Ahiskalioglu A, Aydin ME, Alici HA. (MS 19311) Ultrasound guided erector spinae plane block as a safe and effective method to treat herpes zoster pain. Am J Emerg Med 2019;37(6):1192-4. [CrossRef]

15. Tekin E, Ahiskalioglu A, Aydin ME, Sengun E, Bayramoglu A, Alici HA. High-thoracic ultrasound-guided erector spinae plane block for acute herpes zoster pain management in emergency department. Am J Emerg Med 2019;37(2):375. e1-375.e3. [CrossRef]

16. Ji G, Niu J, Shi Y, Hou L, Lu Y, Xiong L. The effectiveness of repetitive paravertebral injections with local anesthetics and steroids for the prevention of postherpetic neuralgia in patients with acute herpes zoster. Anesth Analg 2009;109(5):1651-5. [CrossRef]

17. Cohen SP, Bicket MC, Jamison D, Wilkinson I, Rathmell JP. Epidural steroids: a comprehensive, evidence-based review. Reg Anesth Pain Med 2013;38(3):175-200. [CrossRef]

18. Han Y, Zhang J, Chen N, He L, Zhou M, Zhu C. Corticosteroids for preventing postherpetic neuralgia. Cochrane Database Syst Rev 2013;(3):CD005582. [CrossRef]

19. Petsas D, Pogiatzi V, Galatidis T, Drogouti M, Sofianou I, Michail $A$, et al. Erector spinae plane block for postoperative analgesia in laparoscopic cholecystectomy: a case report. J Pain Res 2018;11:1983-90. [CrossRef]

20. Tulgar S, Yıldırım A, Karaoglan A, Özer Z. Erector spinae plane block as the main anesthetic method for periparavertebral area surgical procedure. J Clin Anesth 2019;54:157. [CrossRef]

21. Tulgar S, Thomas DT, Suslu H. Ultrasound guided erector spinae plane block relieves lower cervical and interscapular myofascial pain, a new indication. J Clin Anesth 2019;53:74. [CrossRef]

22. Calandese F, Adduci A. Erector spinae plane block for acute postoperative pain management after anterior thoracolumbar spine surgery. J Clin Anesth 2019;52:55-6. [CrossRef]

23. Adhikary SD, Bernard S, Lopez H, Chin KJ. Erector Spinae Plane Block Versus Retrolaminar Block: A Magnetic Resonance Imaging and Anatomical Study. Reg Anesth Pain Med 2018;43(7):756-62. [CrossRef]

24. Schwartzmann A, Peng P, Maciel MA, Forero M. Mechanism of the erector spinae plane block: insights from a magnetic resonance imaging study. Can J Anaesth 2018;65(10):1165-6. [CrossRef]

25. De Cassai A, Tonetti T. Local anesthetic spread during erector spinae plane block. J Clin Anesth 2018;48:60-1. [CrossRef]

26. Kaushal B, Chauhan S, Saini K, Bhoi D, Bisoi AK, Sangdup $T$, et al. Comparison of the Efficacy of Ultrasound-Guided Serratus Anterior Plane Block, Pectoral Nerves II Block, and Intercostal Nerve Block for the Management of Postopera- 
tive Thoracotomy Pain After Pediatric Cardiac Surgery. J Cardiothorac Vasc Anesth 2019;33(2):418-25. [CrossRef]

27. Chen N, Qiao Q, Chen R, Xu Q, Zhang Y, Tian Y. The effect of ultrasound-guided intercostal nerve block, single-injection erector spinae plane block and multiple-injection paravertebral block on postoperative analgesia in thoracoscopic surgery: A randomized, double-blinded, clinical trial. J Clin Anesth 2020;59:106-11. [CrossRef]

28. Kang CM, Kim WJ, Yoon SH, Cho CB, Shim JS. Postoperative Pain Control by Intercostal Nerve Block After Augmentation Mammoplasty. Aesthetic Plast Surg 2017;41(5):10316. [CrossRef]

29. Akkaya T, Ozkan D. Chronic post-surgical pain. Agri 2009;21(1):1-9.

30. Doi K, Nikai T, Sakura S, Saito Y. Intercostal nerve block with $5 \%$ tetracaine for chronic pain syndromes. J Clin Anesth 2002;14(1):39-41. [CrossRef]

31. Reiestad F, Kvalheim L, Mcllvaine WB. Pleural analgesia for the treatment of acute severe thoracic herpes zoster. Reg Anesth 1989;14(5):244-6.

32. Lee HJ, Park HS, Moon HI, Yoon SY. Effect of UltrasoundGuided Intercostal Nerve Block Versus FluoroscopyGuided Epidural Nerve Block in Patients With Thoracic Herpes Zoster: A Comparative Study. J Ultrasound Med 2019;38(3):725-31. [CrossRef]

33. Ferini-Strambi L. Neuropathic Pain and Sleep: A Review. Pain Ther 2017;6(Suppl 1):19-23. [CrossRef]

34. Dworkin RH, Corbin AE, Young JP Jr, Sharma U, LaMoreaux $\mathrm{L}$, Bockbrader $\mathrm{H}$, et al. Pregabalin for the treatment of postherpetic neuralgia: a randomized, placebo-controlled trial. Neurology 2003;60(8):1274-83. [CrossRef]

35. Sabatowski R, Gálvez R, Cherry DA, Jacquot $F$, Vincent $E$, Maisonobe $P$, et al; 1008-045 Study Group. Pregabalin reduces pain and improves sleep and mood disturbances in patients with post-herpetic neuralgia: results of a randomised, placebo-controlled clinical trial. Pain 2004;109(12):26-35. [CrossRef]

36. Freynhagen R, Strojek K, Griesing T, Whalen E, Balkenohl M. Efficacy of pregabalin in neuropathic pain evaluated in a 12-week, randomised, double-blind, multicentre, placebocontrolled trial of flexible- and fixed-dose regimens. Pain 2005;115(3):254-63. [CrossRef]

37. van Seventer R, Feister HA, Young JP Jr, Stoker M, Versavel $M$, Rigaudy L. Efficacy and tolerability of twice-daily pregabalin for treating pain and related sleep interference in postherpetic neuralgia: a 13-week, randomized trial. Curr Med Res Opin 2006;22(2):375-84. [CrossRef]

38. Johnson P, Becker L, Halpern R, Sweeney M. Real-world treatment of post-herpetic neuralgia with gabapentin or pregabalin. Clin Drug Investig 2013;33(1):35-44. [CrossRef]

39. Ding Y, Li H, Hong T, Zhao R, Yao P, Zhao G. Efficacy and Safety of Computed Tomography-Guided Pulsed Radiofrequency Modulation of Thoracic Dorsal Root Ganglion on Herpes Zoster Neuralgia. Neuromodulation 2019;22(1):108-14. [CrossRef]

40. Kim ED, Bak HH, Jo DH, Park HJ. Clinical efficacy of transforaminal epidural injection for management of zosterassociated pain: a retrospective analysis. Skeletal Radiol 2018;47(2):253-60. [CrossRef] 